\title{
The specificity of adaptation of future engineers to pandemic conditions on labor market: a gender perspective
}

\author{
Ekaterina Igorevna Makarenko ${ }^{{ }^{*}}$, Irina Gennadievna Prokhorova $^{2}$, and Asem Hekimoglu \\ Naushabaeva ${ }^{3}$ \\ ${ }^{1}$ Moscow Automobile and Road Construction State Technical University (MADI), Department of \\ Sociology and Management, Moscow, \\ ${ }^{2}$ Financial University under the Government of the Russian Federation, Faculty of Social Sciences \\ and Mass Communications, Moscow, Russia \\ ${ }^{3}$ Bitlis Eren University, Faculty of Economics and Administrative Sciences, Bitlis, Turkey
}

\begin{abstract}
The paper is based on the advance studies of the adaptation of MADI students, future engineers, to the conditions of a forced pandemic associated with the COVID-19 virus. At the first stage of the study (spring 2020), using the content analysis method, the main directions of adaptation and the patterns of future engineers were identified: educational activity, social responsibility, social communication, financial constraints that arose during the period of a sharp change in learning activity, and also the specificity of changes in the place and living conditions, including moving to another region of Russia. At the second stage (spring 2021), using the semi-formalized interview method, a survey of students of the same technical university was conducted about the difficulties faced by boys and girls at the beginning of the pandemic, based on the previously identified directions of adaptation. The results of the study have shown a gender difference in understanding the difficulties of forced adaptation to the conditions of a modern pandemic: girls adapted better to school. The specificity of gender adaptation will help to predict the behavior of graduates of technical universities on labor market in the future.
\end{abstract}

Keywords: gender, gender sociology, economic sociology, future engineers, adaptation, pandemic, distance learning, labor market

\section{Introduction}

Engineering education at all stages of its development plays an extremely important role for the economic development of the country, since the production base and national security of states depend on the quality of training highly qualified technical personnel. Klyucharev rightly notes that the field of engineering education plays an important role in the development of the national economy [1]. Technical education has its own peculiarities when training experts: it requires more practical skills, a serious laboratory base and

\footnotetext{
* Corresponding author: makarenko madi@mail.ru
} 
opportunities for students to directly conduct experiments and master complex fundamental disciplines. In this paper, the object of research is students of technical universities studying under the specialty training program, future engineers; they are representatives of the Russian technical intelligentsia.

Recently, the concept of gender has been increasingly used in the Russian socio-political and scientific field. By itself, this term is not new, but it has a different interpretation from the point of view of Russian and foreign theoretical positions. Thus, Professor Sillaste, the head of the national scientific school "Gender and Economic Sociology" believes that this term can be identified as the category of "gender" and he notes that "the social content of the concept of "gender" is immanently inherent in Russian sociological science" [2]. The modern Western scientific approach often divides these concepts: "gender" is of a biological, physiological nature, and the category of "gender" is social and cultural: Giddens and Sutton believe that the main social understanding of gender lies in its construction: "gender is an unstable social category that can accommodate many variations and can change quite radical" [3]. In particular, scientists believe that once you can change your body, you can also change the socio-cultural grounds for its formation. The Western understanding of gender refers us more to the sociobiological and psychological approaches. Whereas the authors of the paper will adhere to the domestic scientific tradition, considering the specificity of the adaptation of future engineers to the conditions of a pandemic from the point of view of the socio-gender approach, which highlights precisely the social aspects in this complex process.

Turning to the problems of social adaptation in general, it is worth highlighting that it can be voluntary and forced. Voluntary means the direct desire of an individual or a group to change their lifestyle, place of residence, status, and other social indicators. Forced adaptation occurs under the influence of certain conditions that force various societies to leave their usual way of life. We attribute the pandemic (COVID-19) to a forced form of adaptation. The population of the whole world and citizens of many countries find themselves in this difficult situation. In particular, such a social group as students. Russian students, who numbered 4.068.3 thousand people by the beginning of the pandemic (spring 2020) [4], also faced the problem of forced adaptation to the abrupt transition to distance learning. This also affected students of technical universities, who have a long tradition of gender asymmetry towards men. Similar processes took place not only in MADI. This problem is also characteristic of the Financial University. The results of the study are reflected in the article "Gender Equality in Science: Achievements and Problems" [5].

\section{Methods}

The authors have conducted an advanced sociological study on this issue. It was carried out in 2 stages. At the first stage (April-May 2020), 45 student essays were collected by sending an email to one of the authors. Then, 36 works were analyzed by the content analysis method ( 9 were rejected). These were the reflections of students of the Moscow Automobile and Road Construction State Technical University (MADI), studying under the specialty programs, i.e. future engineers. The units of analysis were the following areas of adaptation: (highlighted in order of importance for students)

1. Learning activity

2. Social responsibility

3. Changes in communication

4. Financial and other issues

5. Place and conditions of residence. 
Stage 2: it was conducted during the sociology classes by one of the authors of the paper.

A year later, in April-May 2021, the method of semi-formalized interviews was used with MADI students $(\mathrm{N}=140$; among them were: 104 men and 36 women). The respondents were students of the faculties: design and mechanical, road construction, road transport and management of MADI.

\section{$3 \quad$ Results}

The first stage of the signal research has shown the expected priority of students in adaptation: learning activity. In this regard, in the context of a "sudden" pandemic, students were primarily concerned with the following issues: mastering complex technical disciplines; the impossibility for some students of access to the Internet, the unwillingness of many teachers to work within the framework of distance learning [6].

Social responsibility was associated with the following indicators:

- organization of medical care, work of doctors with coronavirus patients;

- wearing masks and using protective measures;

- volunteer movement among young people, which began to gain momentum at the beginning of the pandemic.

The peculiarities of social communication in these conditions include the fact that it has almost completely moved into virtual space. In financial matters, students turned to new forms of earnings - food delivery and distance working. However, it is worth noting that most of the students in their essays turned to the help of their parents and relatives. It is also necessary to indicate that such a parameter as "changing the place and living conditions" was associated, first, with the departure from the hostel in Moscow. At stage 1, the gender preferences of students were not analyzed.

At the second stage, during a semi-formalized interview, students were asked to assess the importance of the problems that young people face when adapting to a pandemic, as well as to identify it. Immediately, we note that in a year we can state the same priority of adaptation directions for future engineers as it was in 2020. However, the gender preferences of future engineers in terms of adaptation were analyzed.

Table. 1 Preferences in the directions of adaptation to the conditions of the COVID-19 pandemic by gender (in \%).

\begin{tabular}{|c|l|c|c|}
\hline No. & \multicolumn{1}{|c|}{ Indicator } & Men & Women \\
\hline 1 & Learning activity & $75 \%$ & $95 \%$ \\
\hline 2 & Social responsibility & $81 \%$ & $70 \%$ \\
\hline 3 & Social communication & $90 \%$ & $65 \%$ \\
\hline 4 & Financial constraints & $95 \%$ & $52 \%$ \\
\hline 5 & Conditions and place of residence & $75 \%$ & $90 \%$ \\
\hline
\end{tabular}

What do these data say?

In the educational activity, the adaptation of women was more successful. We believe this is due to the fact that women enter universities for technical specialties much more consciously than young men, so their motivation works to achieve success. In turn, one of the authors of the paper, who has been working at a technical university for many years, can confirm this feature. Kolesnikova and Kudenko also argue about this examining the processes of vocational guidance in terms of gender [7]. Reflecting about the specificity of the transition of Russian students to the distance learning in recent years, Zborovsky and Abramova consider it as an increase in the number of student failures and a decline in the 
overall quality of education [8]. It is interesting that in order to improve the quality, foreign scientists (in particular, Tsiatsos Th. from Greece) believe that it is necessary to use gamification to support engineering education [9].

In the article "The importance of constructivism in the teaching social and humanitarian disciplines" [10], these problems were also confirmed based on the results of the study of using new, constructivist elements in pedagogical activity. The need to introduce new elements of constructivism into learning activities is determined by the peculiarities of modern social life, in which virtual digital reality and IT technologies play the main role in the formation of everyday reality.

Let us note that in percentage terms, the problems of social responsibility are of almost equal importance for both girls and boys. Gender parity in this regard is extremely important and testifies to the opportunities for young people, regardless of gender, to express themselves in society. This positive trend reflects the tradition of domestic higher technical education - training a broad educated one who sees and analyzes social problems, who understands what technology and weapons are created for [11]. Modern Western experts are in solidarity with this position of teaching engineering disciplines in Russia. Thus, Zandvoort (Netherlands) directly points out that technical education should be based on such principles as humanitarian and ethical responsibility, since they determine the "social face" of an engineer; and modern engineers who want to be realized in their profession should be ready to build "social design" and the ability to carry out their ideas and mission in public policy [12]. Castro and Sancristobal believe that the training of an engineer in the current context is accompanied by a social understanding of the essence of engineering [13].

Turning to such a parameter as social communication, we understand that we are dealing with a new generation ( $Z$ as it is often called), which uses information technologies in a completely new way than representatives of older ages. "Modern children communicate and learn "online". In addition to the advantages, there are obvious problems here: there is less human communication, they are poorly versed in human emotions and behavior. The Internet comes to the fore as an authority among children, not parents. Virtual communication prevails over real: people communicate more on the Internet, but communicate less in real life" - this is how this generation characterizes... [14] The modern English scientist Mason calls it even the "network generation" and believes that young people, having access to countless information resources, develop completely new values, rules and norms of behavior [15]. It can be seen from the above table that men adapted better under conditions of limited real communication. Young women want more communication with their peers outside of information devices.

Considering such an indicator of adaptation as financial constraints, we expect an increased interest in these issues among male students. Domestic gender stereotypes that a man "bears the burden of responsibility" for financial support is also manifested at the level of students. In addition, during the pandemic, men had more opportunities to earn money. During the interview, the guys were happy to talk about how they were actively involved in the process of making money (unfortunately, sometimes to the detriment of their studies).

The place of residence. Most of the girls have left the hostel and returned home.

The change in living conditions has affected the students living in the hostel to a greater extent. In the spring of 2020, they were all forced to return home. For the girls, this opportunity seemed more attractive. They noted during the interview that communication with loved ones and cooking classes went to their benefit and joy. We also note that women were more disciplined - they "came to the sessions of classes" on time and passed exams better. 


\section{Conclusion}

It should be noted that the study of students of technical universities in the issues of adaptation to the difficult conditions of the pandemic caused by the COVID-19 virus has revealed some difference in these problems in terms of gender. Girls have adapted better in terms of learning activities and its forced transition to online forms and to changes in the place and living conditions; men have found themselves in the implementation of social activity and solving question of finances.

\section{References}

1. G.A. Klyucharev, Soc Res, 3, 51-59 (2020). https://doi.org/10.31857/ S013216250008820-5

2. G.G. Sillaste, Zhenshchiny v mirovoi sotsiologii [Women in world sociology]. (Prometheus, Moscow, 2021)

3. E. Giddens, F. Sutton, Osnovnye ponyatiya v sotsiologii [Essential Concepts in Sociology]. (Higher School of Economics, Moscow, 2019)

4. Federalnaya sluzhba gosudarstvennoi statistiki [Federal State Statistics Service]. Accessed on: October 4, 2021. [Online]. Available: https://rosstat.gov.ru/

5. I.G. Prokhorova, L.A. Brushkova, Self-government, 3(125), 16-19 (2021)

6. E.I. Makarenko, Automobile. Road. Infrastructure, 2(24) (2020)

7. E.M. Kolesnikova, I.A. Kudenko, Bul Peoples' Friendship Univ Rus, 21(2), 239-252 (2021)

8. G.E. Zborovsky, P.A. Ambarova, Soc Res, 3, 17-27 (2021). https://doi.org/10.31857/S013216250012904-7

9. Th. Tsiatsos, Int J Eng Pedag, 10(2) (2020). https://doi.org/10.3991/ijep.v10i2.13771

10. B. Leyla, et al., SHS Web Conf, 103, 01025 (2021). https://doi.org/10.1051/shsconf/202110301025.

11. E.I. Makarenko, Regionology, 28(2), 322-349 (2020). https://doi.org/10.15507/2413-1407.111.028.202002.322-349

12. H. Zandvoort, Engineering Education for a Sustainable, Just and Peaceful Society, in TEK Sustainable Development Seminar. 19 November, 2009. (Helsinki, 2009). https://doi.org/10.13140/2.1.2754.3042

13. M. Castro, E. Sancristobal, Int J Eng Pedag, 10(1), (2020). https://doi.org/10.3991/ijep.v10i1.12927

14. D.O. Nikitina, Sociology, 3, 136-140 (2021)

15. P. Mason, Postkapitalizm: rukovodstvo k nashemu budushchemu [Postcapitalism: a guide to our future]. (Ad Marginem Press, Moscow, 2016) 